\title{
Isolation of a catalytically competent phosphorylated tyrosine kinase from Rous sarcoma virus-induced rat tumor by immunoadsorption to and hapten elution from phosphotyrosine binding antibodies
}

\author{
Susan Whitehouse-Hills ${ }^{1}$, Lawrence S. Argetsinger ${ }^{2}$ and Jules A. Shafer ${ }^{2}$ \\ I Brain Tumor Research Center, The University of California, San Francisco. CA and 2 Department of Biological Chemistry, \\ The University of Michigan, Ann Arbor, MI (U.S.A.)
}

(Received 17 October 1989)

Key words: Tyrosine kinase; pp60 ${ }^{v-s r c}$; Histone kinase activity; Phosphotyrosine; Phosphotyrosine binding antibody

A procedure has been developed for the isolation of a catalytically competent phosphorylated tyrosine kinase (RSV Y-kinase) from avian sarcoma virus-induced rat tumors. The procedure involves reaction of partially purified RSV Y-kinase with ATP to effect tyrosyl phosphorylation of catalytically competent RSV Y-kinase. Tyrosyl phosphorylated RSV Y-kinase was isolated from the heterogeneous reaction mixture by immunoadsorption on immobilized phosphotyrosyl binding antibodies and elution with the hapten p-nitrophenyl phosphate. Estimation of the phosphate content of the purified phosphorylated RSV Y-kinase indicated that 1-3 tyrosyl groups had been phosphorylated upon reaction with ATP. The specific activity toward histone 2B of the purified phosphorylated RSV Y-kinase was at least 30-fold greater than that estimated for the RSV Y-kinase prepared previously by immunoadsorption on immobilized antiserum from tumor bearing rabbits.

\section{Introduction}

pp60 ${ }^{\text {visce }}$, the Rous sarcoma virus (RSV)-transforming factor [1-4] is a kinase [3,5] that catalyzes phosphorylation of tyrosine residues in peptides and proteins (e.g., Ref. 6-9). This $60 \mathrm{kDa}$ enzyme can also undergo autophosphorylation, primarily at Tyr-416 [10-11]. The observation that temperature-sensitive transformation-defective mutants of RSV exhibit reduced kinase activity and are not tyrosyl phosphorylated at the restrictive temperature, suggests that a kinase activity of pp60 $0^{\mathrm{v}-\mathrm{src}}$ may be required for expression of oncogenic activity [5,9,12-13]. Moreover, Balb/c mouse 3 T 3 cells bearing RSV suffer an approx. 1000-fold decrease in tumorigenicity when wild-type RSV is replaced by a variant wherein Tyr-416 in pp60 $60^{\mathrm{v}-s \mathrm{rc}}$ is

\footnotetext{
Abbreviations: RSV Y-kinase, Rous sarcoma virus tyrosine kinase; pp60 ${ }^{\text {v-src }}$, RSV transforming factor; BME, $\beta$-mercaptoethanol; NP-40, Nonidet P-40; Mops, 4-morpholinepropanesulfonic acid; Mes, 4-morpholineethanesulfonic acid
}

Correspondence: J.A. Shafer, Department of Biological Chemistry, P.O. Box 0606, 1301 Catherine Road, Ann Arbor, Ml 48109-0606, U.S.A. replaced by Phe [14]. Additionally, deletion of Tyr-416 in $\mathrm{pp} 60^{\mathrm{v}-\mathrm{src}}$ has been observed to decrease the rate of virus-mediated tumor induction in chicks [15]. Interestingly, wild-type $\mathrm{pp} 60^{\mathrm{v}-\mathrm{src}}$, the Phe-416 variant and variants of $\mathrm{pp} 60^{\mathrm{v}-\mathrm{src}}$, wherein Tyr-416 is deleted, have been reported to exhibit similar tyrosyl kinase activities toward anti-pp $60^{\mathrm{vasc}}$ immunoglobulins in assays where the src kinases were precipitated from crude extracts by the immunoglobulin substrates $[15,16]$. These observations suggest that either, (i) phosphorylation of Tyr-4l6 specifically alters the kinase activity of $\mathrm{pp} 60^{\mathrm{v} \text {-src }}$ toward a physiologically important substrate and thereby enhances its potency as a transforming factor; or (ii) phosphorylation of Tyr-416 alters interactions between pp60 $0^{\mathrm{v} \text { sic }}$ and proteins that exhibit an increased or diminished activity upon binding to pp60 $60^{\mathrm{v}-\mathrm{src}}$. Identification of the molecular basis for the ability of $\mathrm{pp} 60^{\mathrm{v} \text {-src }}$ to effect transformation will require characterization of the interactions of pure phosphorylated pp60 $0^{v-s r c}$ with cellular proteins. In the present paper we describe a procedure for purification of phosphorylated RSV Y-kinase that involves adsorption of the tyrosine phosphorylated kinase on immobilized phosphotyrosine binding antibody and elution of catalytically competent protein with a hapten. The resulting material which should be 
suitable for biophysical studies has a specific enzymatic activity at least 30 -fold greater than that estimated for the $\mathrm{pp} 60^{\mathrm{v}-\mathrm{src}}$ prepared previously by immunoadsorption on immobilized antiserum from tumor-bearing rabbits.

\section{Materials and Methods}

Electrophoresis reagents were purchased from IBI and $\left[\gamma^{-32}\right.$ P]ATP $(5000 \mathrm{Ci} / \mathrm{mmol})$ from Amersham. HA-Ultragel was from LKB, DEAE-Sephacel from Pharmacia and oligo(dA)cellulose from P.L. Biochemicals. D-Serine dehydratase and lipoyl dehydrogenase were the generous gifts of Dr. Michelle Marceau and Dr. Vincent Massey (University of Michigan). Antiserum to $\mathrm{pp} 60^{\mathrm{v} \text {-src }}$, prepared according to the method of Resh and Erikson [17], was kindly supplied by Dr. Raymond L. Erikson (Harvard University). Unless specified, other reagents were from Sigma or Fisher.

B31 cells, a clonal cell line of B77-avian sarcoma virus transformed rat-1 cells (F2408 line of Fischer rat embryo cells), were obtained from Dr. H.E. Varmus, University of California, San Francisco. Tumors were raised in $150-200 \mathrm{~g}$ male Fischer 344 rats by subcutaneous injection of $5 \cdot 10^{5}$ B31 cells into each flank. After 2-3 weeks, tumors were excised, washed in phosphate-buffered saline, frozen in liquid nitrogen and stored at $-70^{\circ} \mathrm{C}$ until further use.

\section{Partial purification of RSV Y-kinase}

A modification and extension of the procedure of Blithe et al. [18] was used to obtain a partially purified enzyme fraction. Frozen tumor $(\mathbf{4 0} \mathrm{g})$ was powdered under liquid nitrogen and homogenized directly in 100 $\mathrm{ml}$ of extraction buffer ( $40 \%$ glycerol, $4 \mathrm{mM}$ EDTA, $0.2 \%$ Nonidet P-40 (NP-40), $100 \mathrm{mM} \mathrm{KCl}, 30 \mathrm{mM}$ $\beta$-mercaptoethanol (BME), $10 \mathrm{mM} \mathrm{KPO}_{4}(\mathrm{pH} 7$ ), $2 \mathrm{mM}$ phenylmethylsulfonyl fluoride (PMSF) and $100 \mathrm{Kal}-$ likrein units of aprotinin per $\mathrm{ml}$ ) by $4 \times 30 \mathrm{~s}$ bursts in a Waring blender, followed by ten up-and-down strokes in a Dounce homogenizer. The homogenate was sonicated for $30 \mathrm{~s}$ using a Labline Ultratip Sonicator at position 10 and then centrifuged for $10 \mathrm{~min}$ at 15000 rpm in a Sorvall RC2-B centrifuge using an SS-34 rotor. The supernatant (S1) was filtered through glass wool and the pellet re-extracted as above. The ensuing supernatant was filtered through glass wool and combined with S1. The combined supernatant was made up to 240 $\mathrm{ml}$ with extraction buffer and centrifuged at $4^{\circ} \mathrm{C}$ in a Beckman ultracentrifuge at $21000 \mathrm{rpm}$ for $180 \mathrm{~min}$ in an SW27 rotor.

Subsequent operations were conducted at $4^{\circ} \mathrm{C}$. The supernatant was filtered through glass wool and applied at a rate of $40 \mathrm{ml} / \mathrm{h}$ to a $96 \mathrm{ml}(2.5 \mathrm{~cm}$ diameter $\times 19.5$ $\mathrm{cm}$ ) bed of HA-Ultragel resin equilibrated with $5 \mathrm{mM}$ $\mathrm{KPO}_{4}(\mathrm{pH} 7$ ), $20 \%$ glycerol, $0.1 \% \mathrm{NP}-40$ and $30 \mathrm{mM}$ BME. The resin was washed with 5 column vol. of equilibrating buffer and protein eluted with $250 \mathrm{ml}$ of $250 \mathrm{mM} \mathrm{KPO}_{4}(\mathrm{pH} \mathrm{7}), 20 \%$ glycerol, 0.1\% NP-40, 30 $\mathrm{mM}$ BME, $5 \mathrm{mM}$ EDTA, $100 \mathrm{mM} \mathrm{KCl}$ and $100 \mathrm{Kal}-$ likrein units of aprotinin per $\mathrm{ml}$. The eluate was dialyzed (using Spectra Por 2 dialysis tubing) for $18 \mathrm{~h}$ against 10 vol. of buffer $\mathrm{A}\left(5 \mathrm{mM} \mathrm{KPO}{ }_{4}(\mathrm{pH} \mathrm{7),20 \%}\right.$ glycerol, $0.1 \%$ NP-40, $30 \mathrm{mM}$ BME and 5 mM EDTA) and the retentate centrifuged for $10 \mathrm{~min}$ at $10000 \mathrm{rpm}$ in a Sorvall centrifuge using an SS-34 rotor. The supernatant was batch-loaded onto $125 \mathrm{ml}$ of DEAE-Sephacel resin (equilibrated with buffer $\mathrm{A}$ ) by slowly rotating the mixture end-over-end for $1 \mathrm{~h}$. The resin was collected by centrifugation for $5 \mathrm{~min}$ at $1000 \mathrm{rpm}$ using an IEC PR-6000 centrifuge. After two, $1 \mathrm{~h}$ washes (260 $\mathrm{ml}$ of buffer A used for each wash) kinase activity was eluted from the resin using $250 \mathrm{ml}$ of buffer A containing $150 \mathrm{mM} \mathrm{NaCl}$; both the washings and the elution were performed in the manner described for batch loading. After dilution with an equal volume of buffer $A$, the eluate was loaded at a rate of $40 \mathrm{ml} / \mathrm{h}$ onto a 14 $\mathrm{ml}(0.90 \mathrm{~cm}$ diameter $\times 22 \mathrm{~cm})$ bed of oligo $(\mathrm{dA})$ cellulose resin equilibrated with buffer $A$. The resin was washed with 3 column vol. of buffer $A$ and protein eluted with a $50 \mathrm{ml}$ linear gradient of $0-1 \mathrm{M} \mathrm{KCl}$ in buffer A containing $20 \mathrm{mM} \mathrm{KPO}_{4}(\mathrm{pH} 7)$. Pooled active fractions $(27.5 \mathrm{ml})$ were dialyzed for $16 \mathrm{~h}$ against $30 \mathrm{vol}$. of buffer A containing $1 \mathrm{mM}$ EDTA and $100 \mathrm{mM} \mathrm{KCl}$. The retentate was loaded onto a $79 \mathrm{ml}(2.5 \mathrm{~cm}$ diameter $\times 16 \mathrm{~cm}$ ) bed of HA-Ultragel resin equilibrated with buffer B (buffer A containing $1 \mathrm{mM}$ EDTA). After washing the resin with 3 column vol. of buffer B, protein was eluted using a $200 \mathrm{ml}$ linear gradient of 5-250 mM KPO $4(\mathrm{pH} \mathrm{7})$ in buffer B. Pooled active fractions $(26.5 \mathrm{ml})$ were dialyzed for $16 \mathrm{~h}$ against $30 \mathrm{vol}$. of enzyme storage buffer (5 mM KPO ${ }_{4}(\mathrm{pH} \mathrm{7),30 \%}$ glycerol, 0.05\% NP-40, $30 \mathrm{mM}$ BME and $1 \mathrm{mM}$ EDTA) and the retentate concentrated 10-fold in an Amicon ultrafiltration apparatus using a YM10 membrane. The resulting partially purified RSV Y-kinase was stored in liquid nitrogen.

\section{Affinity purification of phosphorylated RSV Y-kinase}

An affinity matrix for further purification of RSV Y-kinase was prepared by covalently crosslinking $O$ phosphotyrosine binding antibodies (anti-PY) [19] to $100 \mu \mathrm{l}$ of protein A-Sepharose (3.8 $\mu \mathrm{g}$ antibody per $\mu \mathrm{l}$ protein A-Sepharose) by the method of Schneider et al. [20]. The immobilized anti-PY was then placed in a column and washed with $1 \mathrm{ml}$ of $10 \mathrm{mM} p$-nitrophenyl phosphate (pNPP) in buffer C ( $80 \mathrm{mM}$ Mops (pH 6.7), $6 \mathrm{mM}$ BME and $0.04 \% \mathrm{NP}-40) ; 5 \mathrm{ml}$ of $0.2 \mathrm{M} \mathrm{KPO}_{4}$ (pH 7.5) and $0.1 \%$ Triton X-100; $3 \mathrm{ml}$ of buffer D (150 $\mathrm{mM} \mathrm{NaCl}$ in buffer $\mathrm{C}$ ); and $3 \mathrm{ml}$ of buffer $\mathrm{C}$.

Pre-existing tyrosine phosphorylated proteins were removed by adding $230 \mu \mathrm{l}$ of partially purified RSV Y-kinase to a polypropylene vial containing $23 \mu \mathrm{g}$ of 
aprotinin and $15 \mu \mathrm{l}$ of immobilized anti-PY. The gel and liquid phase were mixed for $20 \mathrm{~min}$ at $4^{\circ} \mathrm{C}$ and then centrifuged to separate the gel and supernatant (S2) phases. (All mixing of gels and liquid phases was performed by end-over-end-rotation of vials containing the two phases.) The gel was washed with $140 \mu 10.05 \%$ NP-40, centrifuged, and the resulting supernatant combined with the supernatant (S2) from the first immunoadsorption. Phosphorylation of RSV Y-kinase was initiated with the addition of $395 \mu \mathrm{l}$ of $125 \mathrm{mM}$ Mops (pH 6.7), 0.03\% NP-40, $10 \mathrm{mM} \mathrm{MgCl}_{2}$ and $100 \mu \mathrm{M}$ $\left[\gamma^{-}{ }^{32}\right.$ P]ATP $(3500 \mathrm{dpm} / \mathrm{pmol})$. After $60 \mathrm{~min}$ at ambient temperature, this solution was added to $30 \mu \mathrm{l}$ of immobilized anti-PY and mixed for $40 \mathrm{~min}$ at $4^{\circ} \mathrm{C}$. The phosphorylated RSV Y-kinase immunoadsorbed on immobilized anti-PY was washed and the gel separated by centrifugation three times with buffer $\mathrm{D}(200 \mu 1)$ and three times with buffer $C(200 \mu l)$. The RSV Y-kinase was then eluted from the immobilized anti-PY by mixing the gel with $60 \mu \mathrm{l}$ of pNPP elution buffer $(10 \mathrm{mM}$ pNPP and $1 \mathrm{mM}$ EDTA in buffer C) for $30 \mathrm{~min}$ at $4^{\circ} \mathrm{C}$. The suspension was separated by centrifugation and the supernatant containing affinity-purified phosphorylated RSV Y-kinase was transferred to a poly(ethylene glycol) treated vial [21] containing $10.5 \mu \mathrm{l}$ of glycerol. The elution procedure was repeated with an additional $60 \mu \mathrm{l}$ of pNPP elution buffer and the eluate combined with the first pNPP eluate. The resulting affinity-purified phosphorylated RSV Y-kinase was stored in liquid nitrogen.

\section{Immunoadsorption of RSV Y-kinase with antibodies to pp $60^{\mathrm{v}-\mathrm{src}}$}

An affinity matrix was prepared by mixing either 50 $\mu \mathrm{g}$ of pp60 ${ }^{\mathrm{v}-\mathrm{src}}$ binding antibodies or $100 \mu \mathrm{g}$ of normal rabbit $\mathrm{IgG}$ in a vial containing $15 \mu \mathrm{l}$ of hydrated protein A-Sepharose and $20 \mu \mathrm{l}$ buffer $\mathrm{C}$ for $1 \mathrm{~h}$ at $4^{\circ} \mathrm{C}$. The gel was washed three times with buffer D $(100 \mu 1)$ and three times with buffer $\mathrm{C}(200 \mu 1)$. A $10 \mu 1$ sample of affinity-purified phosphorylated RSV Y-kinase was mixed at $4^{\circ} \mathrm{C}$ for $1 \mathrm{~h}$ (to effect immunoadsorption) with $15 \mu 1$ of either immobilized antibody to RSV Y-kinase or immobilized rabbit IgG. The immobilized antibody was removed by centrifugation, and $10 \mu \mathrm{l}$ of the supernatant and $3.3 \mu \mathrm{l}$ of quenching solution $(0.12$ $\mathrm{M}$ Tris (pH 6.8), 4\% SDS, 0.004\% Bromophenol blue, $200 \mathrm{mM}$ dithiothreitol and $40 \%$ glycerol) were heated at $95^{\circ} \mathrm{C}$ for $5 \mathrm{~min}$. The immobilized antibody pellet was washed once with buffer D $(200 \mu 1)$, twice with buffer C $(200 \mu \mathrm{l})$ and the washed gel was incubated with $7 \mu 1$ of buffer $\mathrm{C}$ and $7 \mu 1$ quenching solution at $95^{\circ} \mathrm{C}$ for $5 \mathrm{~min}$. The quenched solutions were centrifuged and $10 \mu 1$ of the supernatant from each sample was subjected to SDS-PAGE ( $8.5 \%$ gels).

\section{Kinase activity}

The kinase activity of RSV Y-kinase was determined with histone $2 \mathrm{~B}$ as substrate. A $1 \mu \mathrm{l}$ sample of the fraction to be assayed was incubated with $15 \mu \mathrm{l}$ of 150 $\mathrm{mM}$ Mops ( $\mathrm{pH} 6.7$ ), 0.05\% NP-40 and $2.5 \mathrm{mM}$ BME for $15 \mathrm{~min}$ at room temperature. Phosphorylation was initiated with the addition of $9 \mu \mathrm{l}$ of a solution containing histone $2 \mathrm{~B},\left[\gamma_{-}{ }^{32} \mathrm{P}\right] \mathrm{ATP}$ and $\mathrm{MgCl}_{2}$ to yield a final concentration of $20 \mu \mathrm{M}$ histone $2 \mathrm{~B}, 5 \mathrm{mM} \mathrm{MgCl} 2$ and $50 \mu \mathrm{M}\left[\gamma^{-32} \mathrm{P}\right]$ ATP $(3000 \mathrm{dpm} / \mathrm{pmol})$. After 20,40 or $60 \mathrm{~min}$ (as indicated) $8 \mu \mathrm{l}$ of quenching solution was added and the solution heated at $95^{\circ} \mathrm{C}$ for $5 \mathrm{~min}$. The quenched samples $(10 \mu \mathrm{l})$ were then subjected to SDSPAGE (11.3\% gels).

To allow comparison with published studies [22], the kinase activity was also determined by equilibrating 2.5 $\mu \mathrm{l}$ of affinity-purified phosphorylated RSV Y-kinase with $35 \mu \mathrm{l}$ of $45 \mathrm{mM}$ Mes (pH 6.5) and $0.07 \% \mathrm{NP}-40$ at $22^{\circ} \mathrm{C}$ for $15 \mathrm{~min}$, whereupon $25 \mu \mathrm{l}$ of a solution containing histone $2 \mathrm{~B},\left[\gamma^{-}{ }^{32} \mathrm{P}\right] \mathrm{ATP}$ and $\mathrm{MgCl}_{2}$ was added to yield a final concentration of $33 \mu \mathrm{M}$ histone $2 \mathrm{~B}, 5$ $\mathrm{mM} \mathrm{MgCl}_{2}$ and $1 \mu \mathrm{M}\left[\gamma^{-32} \mathrm{P}\right] \mathrm{ATP}$ (3000 dpm/pmol). After 20,40 and $60 \mathrm{~min}, 18 \mu \mathrm{l}$ of the reaction mixture was added to $6 \mu 1$ of quenching solution and heated for $5 \mathrm{~min}$ at $95^{\circ} \mathrm{C}$. Following SDS-PAGE $(10 \mu 1$ samples $)$ the comparative rate of phosphorylation was determined from the integrated absorbance of autoradiograms of the histone $2 \mathrm{~B}$ bands.

$S D S-P A G E$, protein content and phosphate incorporation

SDS-PAGE was performed as described by Laemmli [23]. Solutions to be analyzed by SDS-PAGE were quenched with quenching solution and heated for $5 \mathrm{~min}$ at $95^{\circ} \mathrm{C}$. Molecular mass standards used were myosin $(200 \mathrm{kDa}), \beta$-galactosidase (116 kDa), phosphorylase $b$ $(92 \mathrm{kDa})$, bovine serum albumin $(66 \mathrm{kDa})$ and ovalbumin (45 kDa). Silver-stained gels were developed according to the method of Morrissey [24]. Autoradiograms were exposed at $-70^{\circ} \mathrm{C}$ using XAR-5 film (Kodak). To estimate protein content and phosphate incorporation, a Zeineh soft laser scanning densitometer (Biomed Instrument, model S1-TRFF) was used to obtain absorbance measurements of the bands on the silver-stained gels and autoradiograms. Protein content was estimated from a linear standard curve relating integrated absorbance to protein content. The standard curve was prepared using $0.5-2 \mathrm{ng}$ of D-serine dehydratase or lipoyl dehydrogenase as a reference standard. Phosphate incorporation into RSV Y-kinase and histone 2B was estimated from an autoradiogram. Standard curves for phosphate incorporation were prepared with the $\left[\gamma^{-}{ }^{32} \mathrm{P}\right] \mathrm{ATP}(3500 \mathrm{dpm} / \mathrm{pmol})$ used to phosphorylate the partially purified RSV Y-kinase. Dilutions containing between 250 and $2000 \mathrm{dpm} / \mu \mathrm{l}$ were prepared and $1 \mu \mathrm{l}$ of each dilution spotted on a blank region of the gel containing the RSV Y-kinase or histone $2 \mathrm{~B}$. 


\section{Acid hydrolysis}

Phosphoserine and phosphothreonine were analyzed by a modification of the method of Hunter and Sefton [6]. Radioactive bands on dried Coomassie-stained gels were localized by autoradiography, excised, placed in a $1.5 \mathrm{ml}$ polypropylene vial containing $40 \mu \mathrm{l}$ of $100 \mathrm{mM}$ $\mathrm{NH}_{4} \mathrm{HCO}_{3}$, ground to a fine powder (with a teflon pestle), suspended in $1.1 \mathrm{ml}$ of $45 \mathrm{mM} \mathrm{NH}_{4} \mathrm{HCO}_{3}$ containing trypsin $(0.9 \mathrm{mg} / \mathrm{ml}$, Worthington $)$ and incubated on a shaker at $37^{\circ} \mathrm{C}$. After $12 \mathrm{~h}$ the gel was separated from the aqueous phase by centrifugation and incubated with $1.1 \mathrm{ml}$ of fresh trypsin/bicarbonate buffer for another $12 \mathrm{~h}$. The aqueous phase from the second digest was separated from the gel, combined with that of the first digest and evaporated. The gel was washed with $100 \mu \mathrm{l}$ of $45 \mathrm{mM} \mathrm{NH} \mathrm{NCO}_{3}$ containing 50 nmol of unlabeled phosphothreonine and phosphoserine. After centrifugation, the supernatant was combined with the residue from the aqueous phases and evaporated. The residue was quantitatively transferred to a Pyrex tube with $150 \mu \mathrm{l}$ of water, the water evaporated and the residue resuspended in $200 \mu \mathrm{l}$ of constant boiling $6 \mathrm{M} \mathrm{HCl}$ (Pierce). The tube was placed in a gas tight vial (Pierce) and purged with $\mathrm{N}_{2}(1 \mathrm{~atm})$. After hydrolysis at $110^{\circ} \mathrm{C}$ for $5 \mathrm{~h}$, the acid was evaporated and the residue taken up in $150 \mu 1$ of water, transferred to a $1.5 \mathrm{ml}$ polypropylene centrifuge tube and again taken to dryness under reduced pressure. The resulting residue was taken up in $0.2 \mathrm{ml}$ of $0.1 \mathrm{M}$ formic acid and processed on a $0.2 \mathrm{ml}$ column of Dowex 50 (Bio Rad) according to the method of Martensen [25]. The fraction that eluted with formic acid, which contained phosphoserine and phosphothreonine but not phosphotyrosine (phosphotyrosine is not eluted from the column by the formic acid) was taken to dryness, the residue taken up in $5 \mu \mathrm{l}$ water, spotted on cellulose TLC plates (Whatman) and electrophoresed at $\mathrm{pH} 3.5$ (pyridine/acetic acid/water $(1: 10: 189 \mathrm{v} / \mathrm{v}))$ for $1 \mathrm{~h}$ at $50 \mathrm{~V} / \mathrm{cm}, 0^{\circ} \mathrm{C}$. Phosphoamino acid reference standards were visualized with ninhydrin and radioactive spots were localized by autoradiography.

\section{Base hydrolysis}

Phosphotyrosine was analyzed by a modification of the method of Martensen and Levine [26]. Radioactive bands from dried Coomassie-stained gels were placed in teflon inserts in reactivials (Pierce) with BSA (0.5 $\mathrm{mg} / \mathrm{ml}$ ) and $5 \mathrm{M} \mathrm{KOH}$ (total volume $200 \mu \mathrm{l}$ ) and hydrolyzed at $155^{\circ} \mathrm{C}$ for $70 \mathrm{~min}$. After transfer to polypropylene vials the hydrolysate was neutralized with $10 \mathrm{M} \mathrm{HClO}_{4}$ and the resulting $\mathrm{KClO}_{4}$ precipitate was removed by centrifugation. The remaining supernatant was made $0.2 \mathrm{M}$ in formic acid and treated with $0.2 \mathrm{ml}$ Dowex [25]. The Dowex resin was washed with $0.1 \mathrm{M}$ formic acid so that the total volume of formic acid solution that passed through the column was $1.1 \mathrm{ml}$.
Phosphotyrosine was eluted from the Dowex 50 with 0.9 $\mathrm{ml}$ of water. The water was evaporated and the residue taken up in $5 \mu \mathrm{l}$ of water and subjected to electrophoresis on cellulose plates as described for acid hydrolysis.

\section{Results and Discussion}

RSV Y-kinase was partially purified from tumors raised in Fisher 344 rats by chromatography on hydroxylapatite, DEAE-Sephacel and oligo(dA)cellulose using procedures similar to those described by Blithe et al. [18]. A solution of the partially purified RSV Y-kinase was treated with anti-PY to remove endogenous tyrosyl phosphorylated proteins and reacted with $\left[\gamma^{32} \mathrm{P}\right] \mathrm{ATP}$ to effect phosphorylation of RSV Y-kinase. Although the partially purified phosphorylated RSV Y-kinase was highly heterogeneous (Fig. 1A, lane A), highly purified tyrosyl phosphorylated RSV Y-kinase could be isolated from this mixture by adsorption to and elution from immobilized anti-PY. Fig. 1A (lane C) shows that the fraction eluted from the immobilized antibody by the hapten pNPP was highly purified and consisted almost entirely of protein which comigrated on SDS-PAGE with proteins in the molecular weight range 57000 58000 . Comparison of lane $C$ in panels $A$ and $B$ of Fig. 1 showed that the ${ }^{32} \mathrm{P}$-labeled material in the eluent comigrated with the major silver-staining bands, consistent with the well documented autophosphorylation of pp60 ${ }^{v-s r c}$. The $M_{r}$ of $57000-58000$ for the RSV Y-kinase is close to that expected for pp60 ${ }^{\mathrm{v}-\mathrm{src}}$ and to the value of 54000 observed by Blithe et al. [18] for the RSV Y-kinase purified from rat tumors by adsorption to and elution from immobilized IgG from TBR sera. The lower than expected $M_{r}$ observed by Blithe et al. [18] for RSV Y-kinase was attributed to proteolytic nicking near the $\mathrm{N}$-terminus. It is not clear whether the higher molecular weight observed for our preparation of RSV Y-kinase reflects less extensive proteolysis of RSV $Y$-kinase or experimental error.

The identity of the 57 and $58 \mathrm{kDa}$ bands as RSV Y-kinase was verified by the observation (Fig. 2) that antibody raised against $\mathrm{pp} 60^{\mathrm{v}-\mathrm{src}}$ (that had been expressed by Escherichia coli) immunoprecipitated ${ }^{32} \mathrm{P}$ labeled material (from affinity purified phosphorylated RSV Y-kinase) that migrated with $M_{\mathrm{r}}$ values of 57000 and 58000 . The presence of two cross-reacting bands migrating with $M_{\mathrm{r}}$ values of 57000 and 58000 (Fig. 1, panel A) is reminiscent of previous observations of Collett et al. [27]. These investigators noted that incubation of partially purified RSV Y-kinase with ATP at concentrations near or above the $K_{\mathrm{m}}(7-36 \mu \mathrm{M}$ $[8,20,28-29])$ led to the production of two phosphorylated species in roughly equivalent amounts which migrated as two closely spaced bands on SDS-PAGE. The band with the lower electrophoretic mobility was more heavily phosphorylated than the faster moving 

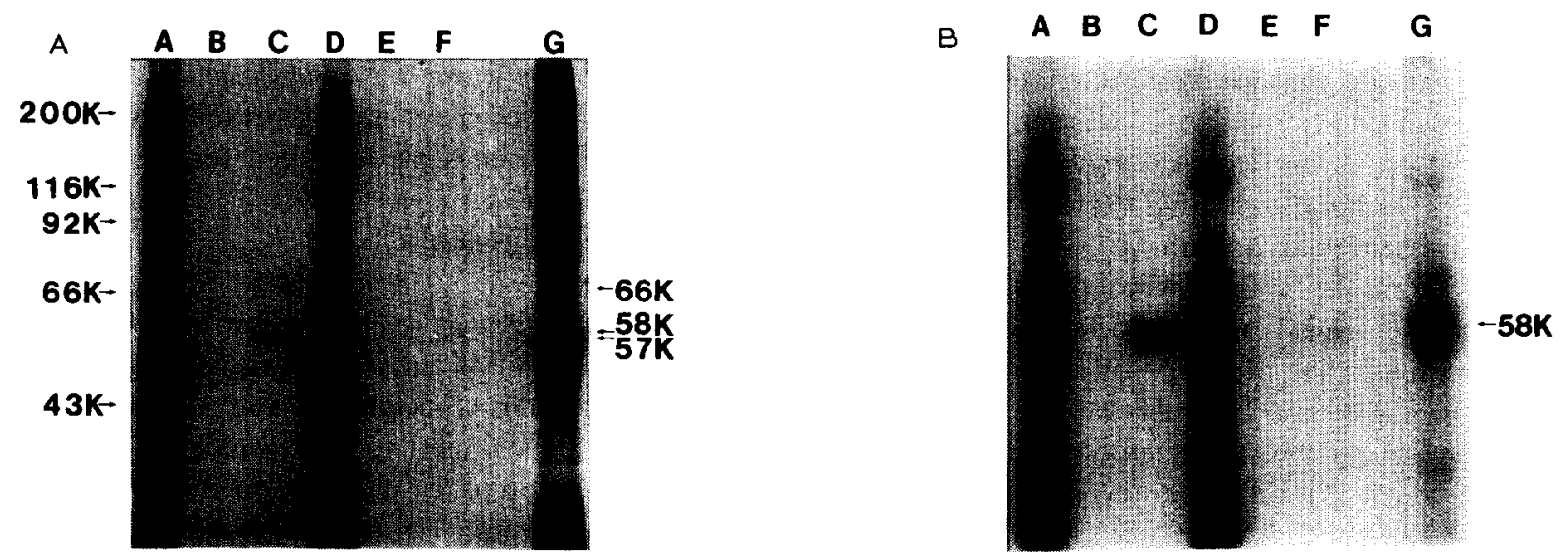

Fig. 1. Purification of RSV Y-kinase by immunoadsorption and elution from immobilized anti-PY. Samples A-F (10 $\mu 1)$ were heated with $3.3 \mu 1$ of quenching solution for $5 \mathrm{~min}$ at $95^{\circ} \mathrm{C}$ and $10 \mu \mathrm{l}$ of the resulting solutions of reduced denatured protein were subjected to SDS-PAGE (8.5\% gel). A silver-stained gel (panel A) and its autoradiogram (panel B) are shown. Samples analyzed were: (A) starting material for affinity purification; (B) wash from the immobilized anti-PY prior to elution with hapten; (C) hapten eluant, (Phosphorylated RSV Y-kinase was eluted from the immobilized anti-PY with $60 \mu \mathrm{l}$ of pNPP elution buffer and $3.5 \mu \mathrm{l}$ of this affinity-purified RSV Y-kinase was diluted with $6.5 \mu \mathrm{l}$ buffer $\mathrm{C}$ and analyzed as sample C); (D) starting material that had been treated twice with immobilized anti-PY to remove phosphorylated RSV Y-kinase; (E) wash from the second immobilized anti-PY prior to hapten elution; (F) hapten eluate from the second immobilized anti-PY: and (G) anti-PY binding material not eluted by hapten. The immobilized anti-PY used for the first immunoadsorption of phosphorylated RSV Y-kinase was washed with $200 \mu 1$ of buffer D, $200 \mu 1$ of buffer $C$ and heated with $36 \mu 1$ of buffer $C$ and $20 \mu 1$ of quenching solution for 5 min at $95^{\circ} \mathrm{C}$. The mixture was centrifuged and $10 \mu$ of the supernatant was subjected to SDS-PAGE.

band which comigrated with unphosphorylated RSV Y-kinase. The structural basis for the decreased mobility of the more heavily phosphorylated species remains to be established as does the reason for the inability of Collett et al. [27] to obtain more than a $50 \%$ yield of the

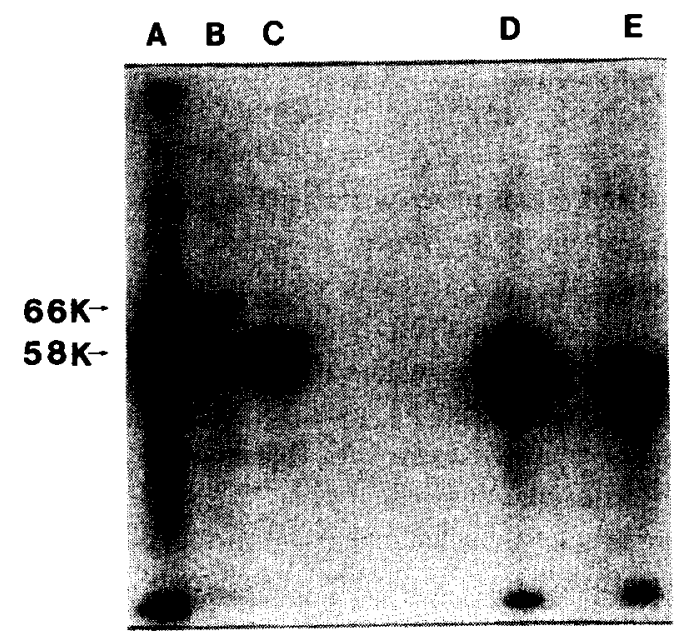

Fig. 2. Immunoadsorption of affinity-purified phosphorylated RSV Y-kinase by immobilized pp60 $0^{\mathrm{v} \text {-src }}$ binding antibodies. A $10 \mu \mathrm{l}$ sample of the affinity-purified phosphorylated RSV Y-kinase was diluted with $5 \mu 1$ of buffer $C$ and treated with either $50 \mu \mathrm{g} \mathrm{pp} 60^{\mathrm{v}-\mathrm{sic}}$ binding antibody or $100 \mu \mathrm{g}$ normal rabbit $\mathrm{IgG}$ immobilized on $15 \mu \mathrm{l}$ of protein A-Sepharose, as described under Materials and Methods. An autoradiogram of the dried gel (after SDS-PAGE) is shown for the following samples: (A) affinity-purified phosphorylated RSV Y-kinase prior to treatment; (B) supernatant remaining after immunoadsorption with immobilized pp $60^{\text {v-src }}$ binding antibodies; (C) supernatant remaining after immunoadsorption with immobilized IgG; (D) material bound by immobilized pp60 $60^{\mathrm{v}-\mathrm{src}}$ binding antibodies; and (E) material bound by immobilized $\operatorname{lgG}$. more heavily phosphorylated derivative. Examination of the autoradiogram in Fig. 2 reveals that affinity purified phosphorylated RSV Y-kinase contains a small amount of phosphorylated protein migrating with a molecular mass of $66 \mathrm{kDa}$. A similar impurity, which like the 66 $\mathrm{kDa}$ protein did not precipitate with $\mathrm{pp} 60^{\mathrm{v}-\mathrm{sc}}$ antiserum, was reported by Neer and Lok [30] as a $64 \mathrm{kDa}$ contaminant in their preparation of a $\mathrm{pp} 60^{\mathrm{v}-\mathrm{src}}$ related tyrosine kinase from bovine brain. As pointed out by Neer and Lok [30] the contaminant may be a tyrosine kinase or a substrate for one.

It is important to note that purification occurred during both the adsorption and elution steps in the treatment of phosphorylated RSV Y-kinase with immobilized anti-PY. Phosphorylated RSV Y-kinase was specifically eluted from anti-PY by hapten (compare lanes B and C of Fig. 1). The yield of adsorbed RSV Y-kinase recovered by elution with the hapten was $47 \%$. Although several proteins were adsorbed on the immobilized anti-PY, only phosphorylated RSV $Y$-kinase appeared to be eluted from the resin by the hapten (compare lanes $\mathrm{C}$ and $\mathrm{G}$ of Fig. 1). The observation that little additional phosphorylated RSV Y-kinase was obtained after a second immunoadsorption with additional immobilized anti-PY suggests that the first immunoadsorption step captured most of the phosphorylated RSV Y-kinase (compare Fig. 1, lanes C and F). Control experiments (data not shown) showed that when the starting material for affinity chromatography was not treated with anti-PY prior to incubation with ATP the yield of the $57-58 \mathrm{kDa}$ protein was not altered. This observation suggests that prior to addition of ATP little 
of the RSV Y-kinase in the partially purified material contains phosphorylated tyrosine residues.

A standard curve relating the amount of silver-stained protein standards to integrated absorbance, and a standard curve that related the amount of a $\left[\gamma-{ }^{32}\right.$ P]ATP standard to the integrated absorbance of an autoradiogram, were used to estimate the extent of incorporation of phosphate into RSV Y-kinase from the integrated absorbance of RSV Y-kinase on silver-stained gels and autoradiograms. Assuming the response of RSV Y-kinase to the silver stain is the same as that of a lipoyl dehydrogenase or $D$-serine dehydratase protein standard, the radioactivity of the RSV Y-kinase band as judged from the intensity of the autoradiogram indicated 1.4 (lipoyl dehydrogenase standard) or 2.8 (Dserine dehydratase standard) phosphoryl groups were incorporated per molecule of RSV Y-kinase. Thus, the variation of proteins with respect to their response to silver stain introduces considerable uncertainty in estimates of the extent of phosphorylation of RSV Y-kinase. Phosphoamino acid analysis after limited acid and base hydrolysis of the affinity purified RSV Y-kinase indicated that it had been phosphorylated almost exclusively on tyrosine residues upon treatment with $\left[\gamma_{-}{ }^{32}\right.$ P]ATP. (compare Fig. 4 , panels A and B, lane A). Fig. 3 shows that most of the histone kinase activity in the starting material for affinity purification of phos-

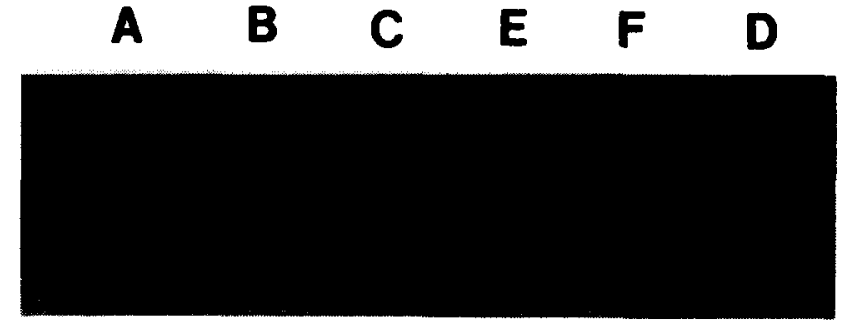

Fig. 3. Phosphorylation of histone $2 \mathrm{~B}$ by fractions from the purification of RSV Y-kinase. Histone $2 \mathrm{~B}$ was phosporylated in the presence of $5 \mathrm{mM} \mathrm{MgCl} 2,50 \mu \mathrm{M}\left[\gamma^{-32} \mathrm{P}\right] \mathrm{ATP}$ at $\mathrm{pH} 6.7$ by $1 \mu \mathrm{l}$ of samples A-F described in the legend to Fig. 1 . After $1 \mathrm{~h}$ the reaction was quenched and $10 \mu \mathrm{l}$ samples were subjected to SDS-PAGE. An autoradiogram of the dried SDS-PAGE is shown. Fractions assayed were: (A) starting material; (B) wash prior to hapten elution of phosphorylated RSV Y-kinase in the first treatment with anti-PY; (C) hapten eluate of phosphorylated RSV Y-kinase from immobilized anti-PY during the first treatment with anti-PY; (D) starting material remaining after two treatments with immobilized anti-PY; (E) wash prior to elution of phosphorylated RSV Y-kinase during the second treatment; and $(F)$ hapten eluate of phosphorylated RSV Y-kinase in the second treatment.

phorylated RSV Y-kinase did not bind to the immobilized anti-PY (compare lanes A, C and D). The observation that the unadsorbed material phosphorylated histone primarily on serine and threonine, whereas the phosphorylated RSV Y-kinase phosphorylated histone almost exclusively on tyrosine (compare lanes B and C
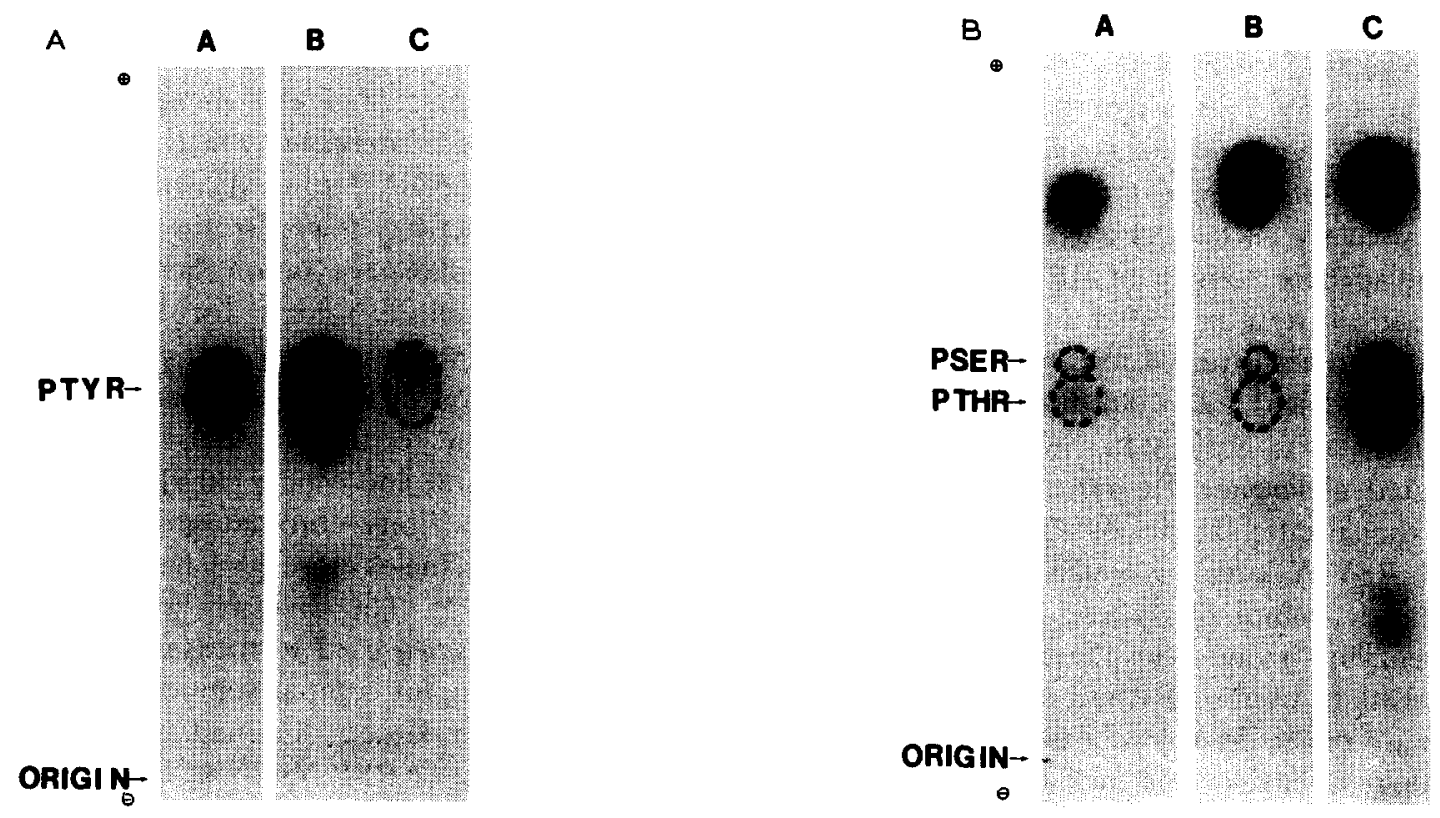

Fig. 4. Characterization of phosphoamino acids. Proteins were separated by SDS-PAGE, localized by autoradiography, excised from the dried gels and subjected to either base or acid hydrolysis. Panel A, samples were subjected to base hydrolysis in $5 \mathrm{M} \mathrm{KOH}$ at $155^{\circ} \mathrm{C}$ for 70 min followed by partial purification on Dowex 50 and electrophoresis of the phosphotyrosine containing fraction on cellulose plates. Panel B, samples were subjected to partial proteolysis with trypsin to solubilize phosphopeptides followed by acid hydrolysis in $6 \mathrm{M} \mathrm{HCl}$ for $5 \mathrm{~h}$ at $110^{\circ} \mathrm{C}$, a treatment with Dowex 50 and electrophoresis on cellulose plates of the fraction containing phosphoserine and phosphothreonine. Autoradiograms of the cellulose plates are shown and the migration of the standards identified. Samples analyzed were: (A) phosphorylated RSV Y-kinase after purification on immobilized anti-PY; (B) histone 2B phosphorylated by $1 \mu \mathrm{l}$ of affinity-purified phosphorylated RSV Y-kinase; and (C) histone 2B phosphorylated by $1 \mu \mathrm{l}$ of a solution of starting material that had been treated twice with anti-PY to remove phosphorylated RSV Y-kinase (sample

D in Fig. 1). (PSER, phosphoserine; PTHR, phosphothreonine; and PTYR, phosphotyrosine) 


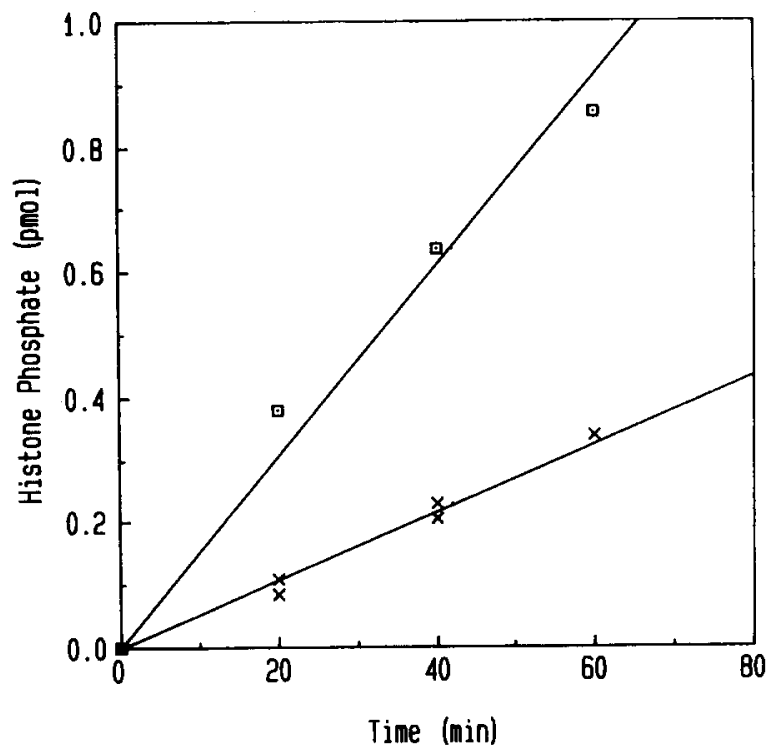

Fig. 5. Activity of phosphorylated RSV Y-kinase toward histone 2B. Phosphorylations were catalyzed by $0.87 \mathrm{ng}$ of affinity-purified phosphorylated RSV Y-kinase in the presence of either $50 \mu \mathrm{M}$ ATP ( $\square$ ) or $1 \mu \mathrm{M}$ ATP $(X)$ as described under Materials and Methods. At the indicated times, aliquots of the assay mixtures were quenched and 10 $\mu l$ of each quenched sample was subjected to SDS-PAGE. An autoradiogram of the dried gel was analyzed using a soft laser densitometer.

of panels A and B, Fig. 4) supports the conclusion (see above) that the immobilized anti-PY adsorbed essentially all of the RSV Y-kinase.

Fig. 5 depicts time dependencies for the incorporation of phosphate into histone $2 \mathrm{~B}$ by affinity purified phosphorylated RSV Y-kinase in the presence of $50 \mu \mathrm{M}$ ATP ( $\mathrm{pH}$ 6.7) (the conditions routinely used in this paper) and in the presence $1 \mu \mathrm{M} \mathrm{ATP}(\mathrm{pH} 6.5$ ) (the conditions used by Richert et al. [22] for the measurement of the specific activity of RSV Y-kinase purified by immunoadsorption on immobilized TBR-sera which contained antibodies directed toward $\mathrm{pp} 60^{\mathrm{v}-\mathrm{src}}$. The two assay conditions yield a 2.8 -fold difference in the initial rate of histone phosphorylation. Standard curves relating integrated absorbance to phosphate content indicated that the specific activity of affinity-purified phosphorylated RSV Y-kinase isolated using immobilized anti-PY was 1.1 pmol phosphate transferred per min per pmol enzyme-bound phosphate, when assayed under the conditions used by Richert et al. [22]. Since each RSV Y-kinase molecule must contain at least one tyrosine phosphate to have bound to the anti-PY used in the purification procedure, the quoted specific catalytic activity of affinity-purified RSV Y-kinase should be considered as a lower limit. This value is approx. 30-fold higher than that reported $(0.037$ pmol per min per pmol enzyme) for the enzyme purified by immunoadsorption on immobilized TBR-sera. Thus, it appears that only a small fraction of RSV Y-kinase purified by affinity chromatography on immobilized TBR-sera was catalyti- cally competent. The low catalytic competence of the TBR-sera purified material was due in part to denaturation under the conditions necessary to elute RSV Y-kinase from immobilized TBR-sera. Blithe et al. [18] have pointed out that the high concentration of $\mathrm{KSCN}$ needed to elute pp $60^{v-s r c}$ from the immobilized TBRserum was destructive to kinase activity and that recovery of activity was always less than $40 \%$ of that applied to the immobilized TBR-serum. Additionally, the low catalytic activity might be due in part to the presence of catalytically incompetent RSV Y-kinase in the material applied to the immobilized TBR-sera. In this regard it is interesting to note that in studies wherein anti-PY was used to purify phosphorylated insulin receptor, the insulin receptor in crude extracts of human placenta was shown to be a mixture of nicked and intact receptor. The nicked receptor, which accounted for approx. $85 \%$ of the insulin binding activity, was catalytically incompetent as demonstrated by its failure to undergo either insulin-promoted autophosphorylation or activation as a kinase [19]. It is unlikely that a substantial fraction of the difference in the kinase activity of the two preparations was due to the fact that in one preparation RSV Y-kinase was phosphorylated and in the other it was not, since the unphosphorylated RSV Y-kinase would be expected to become phosphorylated under the conditions used to measure activity. Moreover, detailed studies [31] of the effect of phosphorylation on the activity of $\mathrm{pp} 60^{\mathrm{v}-\mathrm{src}}$ suggest that autophosphorylation of pp60 $0^{\mathrm{v}-\mathrm{src}}$ has little effect on its kinase activity toward exogenous substrates. It is interesting to note that a proteolytically nicked form of $\mathrm{pp} 60^{\mathrm{v}-\mathrm{src}}$, $\mathrm{p} 52^{\mathrm{v}-\mathrm{scc}}$, has been identified which shows a higher kinase activity than $\mathrm{pp} 60^{\mathrm{v}-\mathrm{src}}$ toward certain protein substrates, and a lower activity towards others [32]. p52 $2^{\mathrm{v}-\mathrm{src}}$ fails to undergo autophosphorylation, however. Since our purification procedure selects for tyrosylphosphorylated protein, it is not surprising that $\mathrm{p} 52^{\mathrm{v}-\mathrm{src}}$ is absent from our preparation of RSV Y-kinase.

In addition to the immunoaffinity procedures of Blithe et al. [18] and others [33,9] utilizing immobilized TBR-serum, affinity chromatography on ADP-agarose [31] and tyrosine-agarose [34] have been employed to purify pp $60^{v-s r c}$. The diversity and complexity of the protein substrates used to measure kinase activity precludes meaningful comparisons of the catalytic properties of RSV Y-kinase obtained by these earlier procedures to those of RSV Y-kinase obtained by the procedures outlined in this study.

The observation that a 50 -fold increase in the ATP concentration (from 1 to $50 \mu \mathrm{M}$ ) produced only a 2.8 -fold increase in rate, suggests that at $50 \mu \mathrm{M}$ ATP phosphorylated RSV Y-kinase is nearly saturated with respect to ATP. This conclusion is consistent with the values of 7-36 $\mu \mathrm{M}$ reported for the $K_{\mathrm{m}}$ for ATP for RSV Y-kinase $[8,22,28,29]$. If the phosphorylated RSV 
Y-kinase were saturated with respect to ATP and histone in the presence of $50 \mu \mathrm{M}$ ATP and $20 \mu \mathrm{M}$ histone, the velocity observed under these conditions would indicate a turnover number of $0.051 \mathrm{~s}^{-1}(1.1 \cdot 2.8 / 60)$. If the $K_{\mathrm{m}}$ for histone is well above $20 \mu \mathrm{M}$ the ratio of the velocity at saturating ATP to the histone concentration would yield an estimate of $2.6 \cdot 10^{3} \mathrm{M}^{-1} \cdot \mathrm{s}^{-1}$ for the specificity constant $\left(k_{\text {cat }} / K_{\mathrm{m}}\right)$ for phosphorylated RSV Y-kinase complexed with ATP. In contrast to these values, the corresponding turnover number and specificity constant of hexokinase (with ATP and glucose as substrates) are $1300 \mathrm{~s}^{-1}$ and $1.3 \cdot 10^{7} \mathrm{M}^{-1} \cdot \mathrm{s}^{-1}$, respectively [35]. The observation that the activity of phosphorylated RSV Y-kinase (toward histone 2B) is 3-4 orders of magnitude below that of hexokinase (toward glucose) may simply reflect the fact that histone 2B is not the physiological substrate of phosphorylated RSV Y-kinase. Hopefully, the method in this study for isolation of forms of RSV Y-kinase competent to undergo autophosphorylation will facilitate identification of physiologically important substrates of pp60 $0^{\text {v-src }}$.

\section{Acknowledgements}

The authors are happy to acknowledge technical assistance from Mr. Felix D. Karim and John Dutton, and helpful advice and encouragement from Dr. Victor A. Levin. Grants DK35249 and CA 37655 from the United States Public Health Service supported the investigations in this study that were done at The University of Michigan and The University of California, respectively. Part of the studies presented in this paper are described in a Ph.D. dissertation to be submitted by L.S.A. to The Graduate School of The University of Michigan.

\section{References}

1 Brugge, J.S. and Erikson, R.L. (1977) Nature (Lond.) 269, 346-348.

2 Purchio, A.F., Erikson, E., Brugge, J.S. and Erikson, R.L. (1978) Proc. Natl. Acad. Sci. USA 75, 1567-1571.

3 Levinson, A.D., Oppermann, H., Levintow, L., Varmus, H.E. and Bishop, J.M. (1978) Cell 15, 561-572.

4 Collett, M.S., Erikson, E. and Erikson, R.L. (1979) J. Virol. 29, 770-781.

5 Collett, M.S. and Erikson, R.L. (1978) Proc. Natl. Acad. Sci. USA 75, 2021-2024.
6 Hunter, T. and Sefton, B.M. (1980) Proc. Natl. Acad. Sci. USA 77, 1311-1315.

7 Sefton, B.M., Hunter, T., Beemon, K. and Eckhart, W. (1980) Cell 20, 807-816.

8 Collett, M.S., Purchio, A.F. and Erikson, R.L. (1980) Nature (Lond.) 285, 167-169.

9 Levinson, A.D., Oppermann, H., Varmus, H.E. and Bishop, J.M. (1980) J. Biol. Chem. 255, 11973-11980.

10 Smart, J.E., Oppermann, H., Czernilofsky, A.P., Purchio, A.F., Erikson, R.L. and Bishop, J.M. (1981) Proc. Natl. Acad. Sci. USA 78, 6013-6017.

11 Patschinsky, T., Hunter, T., Esch, F.S., Cooper, J.A. and Sefton, B.M. (1982) Proc. Natl. Acad. Sci. USA 79, 973-977.

12 Rubsamen, H., Friis, R.R. and Bauer, H. (1979) Proc. Natl. Acad. Sci. USA 76, 967-971.

13 Sefton, B.M., Hunter, T. and Beemon, K. (1980) J. Virol. 33, 220-229.

14 Snyder, M.A. and Bishop, J.M. (1984) Virology 136, 375-386.

15 Cross, F.R. and Hanafusa, H. (1983) Cell 34, 597-607.

16 Snyder, M.A., Bishop, J.M., Colby, W.W. and Levinson, A.D. (1983) Cell 32, 891-901.

17 Resh, M.D. and Erikson, R.L. (1985) J. Cell Biol. 100, 409-417.

18 Blithe, D.L., Richert, N.D. and Pastan, I.H. (1982) J. Biol. Chem. 257, 7135-7142.

19 Pang, D.T., Sharma, B.R. and Shafer, J.A. (1985) Arch. Biochem. Biophys. 242, 176-186.

20 Schneider, C., Newman, R.A., Sutherland, D.R., Asser, U. and Greaves, M.F. (1982) J. Biol. Chem. 257, 10766-10769.

21 Latallo, Z.S. and Hall, J.A. (1986) Thromb. Res. 43, 507-521.

22 Richert, N.D., Blithe, D.L. and Pastan, 1. (1982) J. Biol. Chem. 257, 7143-7150.

23 Laemmli, U.K. (1970) Nature (Lond.) 227, 680-685.

24 Morrissey, J.H. (1981) Anal. Biochem. 117, 307-310.

25 Martensen, T.M. (1984) Methods Enzymol. 107, 3-23.

26 Martensen, T.M. and Levine, R.L. (1983) Methods Enzymol. 99, 402-405.

27 Collett, M.S., Wells, S.K. and Purchio, A.F. (1983) Virology 128, 285-297.

28 Wong, T.W. and Goldberg, A.R. (1984) J. Biol. Chem. 259 , 3127-3131.

29 Graziani, Y., Erikson, E. and Erikson. R.L. (1983) J. Biol. Chem. $258,6344-6351$.

30 Neer, E.J. and Lok, J.M. (1985) Proc. Natl. Acad. Sci. USA 82, 6025-6029.

31 Sugimoto, Y., Erikson, E., Graziani, Y. and Erikson, R.L. (1985) J. Biol. Chem. 260, 13838-13843.

32 Wells, S.K. and Collett, M.S. (1983) J. Virol. 47, 253-258.

33 Erikson, R.L., Collett, M.S., Erikson, E. and Purchio, A.F. (1979) Proc. Natl. Acad. Sci. USA 76, 6260-6264.

34 Fukami, Y. and Lipmann, F. (1985) Proc. Natl. Acad. Sci. USA 82, 321-324.

35 Colowick, S.P. (1973) in The Enzymes, 3rd Edn. (Boyer, P.D., ed.), Vol. 9, pp. 1-48, Academic Press, New York. 